\section{Estética, nuevos materiales y funcionalidad eficiente: la agencia medioambientalista de los objetos de Marjan van Aubel}

AESTHETICS, NEW MATERIALS, AND EFFICIENT FUNCTIONALITY: THE ENVIRONMENTALIST AGENCY OF MARJAN VAN AUBEL'S OBJECTS

Marjan van Aubel es diseñadora de DesignLAB de Gerrit Rietveld Academy (Ámsterdam) y Máster en Design Products del Royal College of Art (Londres). En los últimos años ha recibido múltiples premios, entre los que destacan

"Designer of The future" (Winner, 2017), "Wired Innovation Award" (Winner, 2016) y "Swarovski Young Emerging Talent Medal" (Winner, 2015). Su trabajo, que equilibra sustentabilidad, materiales y tecnología, destaca por su alcance político en tanto está pensado para generar un cambio en la conciencia y los hábitos de los consumidores. Este artículo explora las distintas formas en que opera este impacto a través del análisis de la agencia de los objetos en los proyectos Current Window (2015), Current Table (2014) y Well Proven Chair (2013).

Marian van Aubel is a designer from DesignLAB at Gerrit Rietveld Academy (Amsterdam) and Master's in Design Products from Royal College of Art (London). In the last few years she has received several awards, among the most important ones are "Designer of the future" (Winner, 2017), "Wired Innovation Award" (Winner, 2016) and "Swarovski Young Emerging Talent Medal" (Winner, 2015). Her work, which balances sustainability, materials and technology, stands out for its political reach that comes from it having been conceived to generate changes in awareness and habits of consumers. This article explores the different forms in which this impact operates by analysing the agency of objects in her projects Current Window (2015), Current Table (2014) and Well Proven Chair (2013).

CATALINA MANSILLA Pontificia Universidad Católica de Chile
Santiago, Chile clmansilauccl el quehacer del diseño contemporáneo, se vuelve interesante explorar el impacto que los objetos de de uso $y$ circulacion. Considerando las propuestas teoricas que han relevado la agencia la consideración de los objotos como elementos que generan modificaciones en el comportamiento, las costumbres y las preocupaciones sociales de una época. En este sentido, los objetos pueden alcanzar un impacto político considerable, gestionando cambios sociales en el ámbito público o privado a
Within the possible political spheres where the discipline and practice of to explore the impact that design objects have in their contexts of use and proposals that the social agency of objects as elements that generate modifications in the behaviours, uses and social concerns of an era, has gained force In this sense, objects can reach considerable political impact managing social changes in the public or private spheres through their interaction with users. circulation. Considering the theoretical
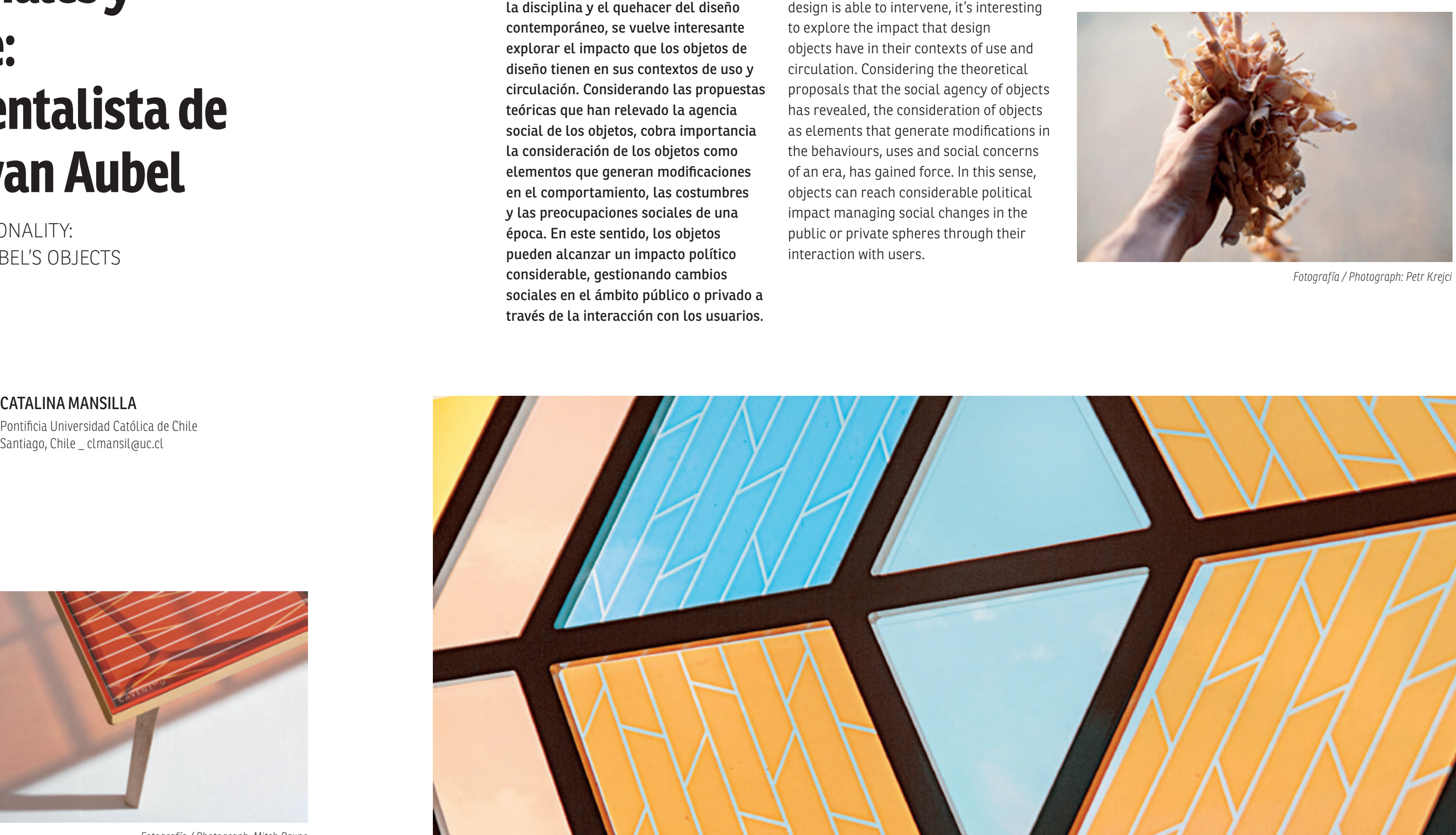

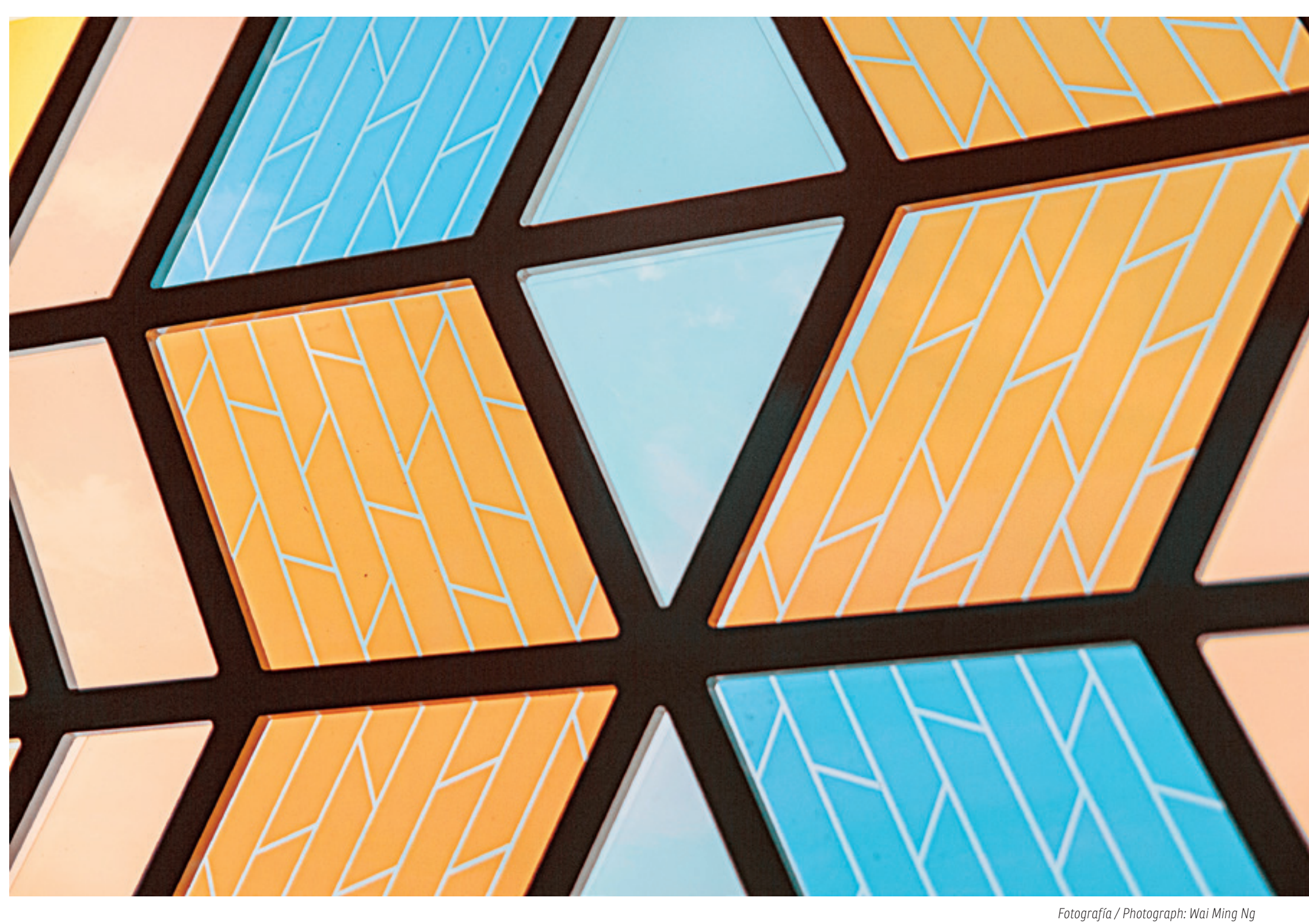


En el caso de los objetos de diseño sustentable de Marjan van Aubel, política medioambientalista que busca ransformar el carácter de prácticas cotidianas, volviéndolas mucho más responsables con el medio ambiente. A partir de esta observación, en este de diseño de Van Aubel operan agentes de cambio social para un planeta más sustentable, interact con los usuarios desde sus propiedades materiales, para provocar cambios de comportamiento socioambiental des los espacios privados y cotidianos en que circulan. Dicha agencia social operaria a traves de tres movimientos: estética del objeto.

OBJETOS DE DISEÑO COMO

EL EJERCICIO POLITICO DEL DISE

EN ENTORNOS COTIDIANOS DISEÑ

Como esfuerzo teórico de las ciencias sociales que releva el rol de las cosas en destaca la propuesta de que existe una agencia social de los objetos, y que, por tanto, estos constituyen parte importan de la conformación y reproducción de Las formas sociales. Esta idea, fundada sobre el concepto de agencia que destaca primeramente eltrabajo de Bruno considera que la agencia no constituy únicamente una capacidad atribuible los seres humanos $-y$ gue los definiri esencialmente como "sujetos" - , sino qu también se puede aplicar a la esfera de lo no-humano y/o de los objetos (Mille 2005). Junto con levantar una crítica radical a la oposición moderna objetosus cosas complica asumir que aptcado a las cosasimplca asu a que estasposen las personasy las sociedades, en tant que son capaces de entrar en la esfera de las interacciones sociales, intencionando, provocando y transformando estas

relaciones (Gell, 1998).

En el caso de los llamados new

material culture studies, perspectiva

antropológica de corriente inglesa
In the case of Marjan van Aubel's sustainable design objects, this impact is politics that seeks to transform the character of everyday practices, makin them much more environmentally responsible. Based on this observation, operate as asents of socia chang a more sustainats of acial change for with users from within their own mater properties, to motivate changes in social-environmental behaviour from within the private and everyday spaces in which they circulate. This social agency would operate by means of the movements. functionality, material ics of the object.

\section{DESIGN OBJECTS AS AGENTS} OF SOCIAL CHANGE, OR THE POLTICAL EXERCISE OF DESIGN

As a to As a theoreticat effort of the social in the study of sociahts the role of things notion stands out that there is a social agency of objects, and that, consequen these constitute an important part in the conformation and reproduction of the social forms. This idea, founded on the concept of agency that first stands out in the work of Latour (1993) and Alfred Gell (1998), considers that the ageney does not solely constitute a capacity that it would define them essentially 'subjects' - , but that can also be applie to the sphere of the non-human and or of objects (Miller, 2005). Together with raising a critique of the radical contemporary opposition object-subject, the concept of agency applied to things mplies to assume that these things possess a spectic status in relation capable of entering the sphere of social interactions, influencing, provoking and transforming these relations (Gell, 1998). In the case of the so-called 'new material culture studies', an Englishthat has focused on the study of los múltiples objetos que circulan en

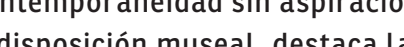
comprensión de los objetos como elementos activos en las relaciones sociales, aun cuando su forma de agenciamiento sea diferente a la de los seres humanos. Es también una de otras perspectivas de estudio la científico-positivista, que pretende la descripción, taxonomización. e historización de la cosa; o la propuesta semiótica, que realiza una lectura de los objetos como texto, símbolo o metáfora, to que desemboca paulatinamente en una cosas (Domańska, 2006). Destacan en esta línea Daniel Miller (1987, 2005) e lan Woodward (2007) quienes acentúan que las cosas no solo existen -aunque a menudo no seamos conscientes de su presencia$y$ configuran nuestra realidad perceptible, sino que además poseen un fuerte poder performativo en tanto per ejoct fas cosas resula relaciones sociales del ámbito público de un grupo humano, en tanto pueden implicar un determinado estatus social o configurar la identidad de una persona (Woodward, 2001).

\section{En una propuesta más reciente,}

Tim Ingold (2010) ha subrayado la mportancia de concebir las cosas ya no como "objetos" -inanimados, ontológicamestea "sos, op sino como "cosa" (thing) viva, en

permanente transformación, cambio interacción (2010). Ingold refuerza la idea de que las cosas materiales son más bien procesos, cuya real agencia radica en que no pueden ser contenidas o capturadas. El autor plantea una se adhiere flujo que a la ida tancepción de or el pensamiento

occidental, que la considera un sólido y diferenciado por la superposición de la forma cultural (2010). multiple objects that circulate in the contemporaneity, devoid of any emerges an understanding of objects active elements in the social relations, even though their way of agency may be different from that of human
beings. It is also a theoretical proposal beings. It is also a theoretical propo study perspectives associated with material culture, such as the scientificpositivist, that proposes the description, taxonomization and historization of the thing; or the semiotic proposal, that performs a reading of objects as text, symbol or metaphor, leading eventually to a de-materialised perception of things (Domańska, 2006). In this line, Wha Daniel Milter $(1987,2005)$ and lan not only do exist - although we are often not conscious of their presence - and configure our perceptible reality, but they also possess a strong performative power as social agents. Things are, for hrtance, fundamental for socia relations in the public sphere of a given human group, as they can imply a certain social status or configure the In a more recent proposal, Tim Ingold (2010) has underlined the importance conceiving things no longer as 'objects' -inanimate, passive, static, ontologically opposed to the "subject" - , but as a liv thing' in permanent transformation change and interaction (2010). Ingold stresses the notion that material thing are rather processes, whose real agency contained or captured. The author poses new definition of materiality that is better attached to the conce than the notion traditionally sketched by Western thought, which considers it a solid and homogeneous precipitade that waits to be differentiated by the
Desde esta perspectiva, insiste (2010), el foco de los estu (e) que originan la forma y permit su crecimiento, circulación y transformación material, que en e con esta lógica, la función de los reduloge, la fincios de los diseñadores-en el universo de las cosas no es imponer una for materia, sino poner en asociación diversas materias, combinando y redirigiendo su flujo hacia lo que podría emerger y está ya prefigur encol. Esto significa que ta tarea productor no consiste en reproduci nte una idea preconcebida sino en unir y seguir las fuerzas $y$ flujos de la materia que llevan generar la forma de la obra. Desde la teoría del diseño, destacado por Ezio Manzini, quien el contexto de una creciente "crisis de identidad" de los materiales subraya el valor de la presencia y comportamiento de los materiates veces permas que, aunque tantas hacen posible la actual sociedad de $L$
información e incluso posibilitan la existencia de las múltiples realidades virtuales, "inmateriales", que abunda en el escenario contemporáneo:

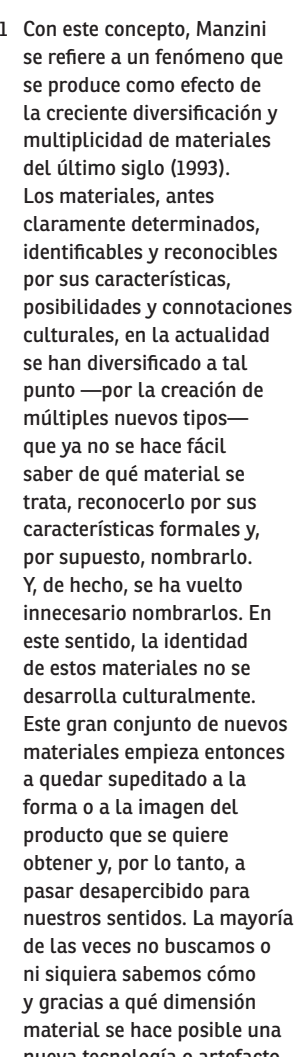

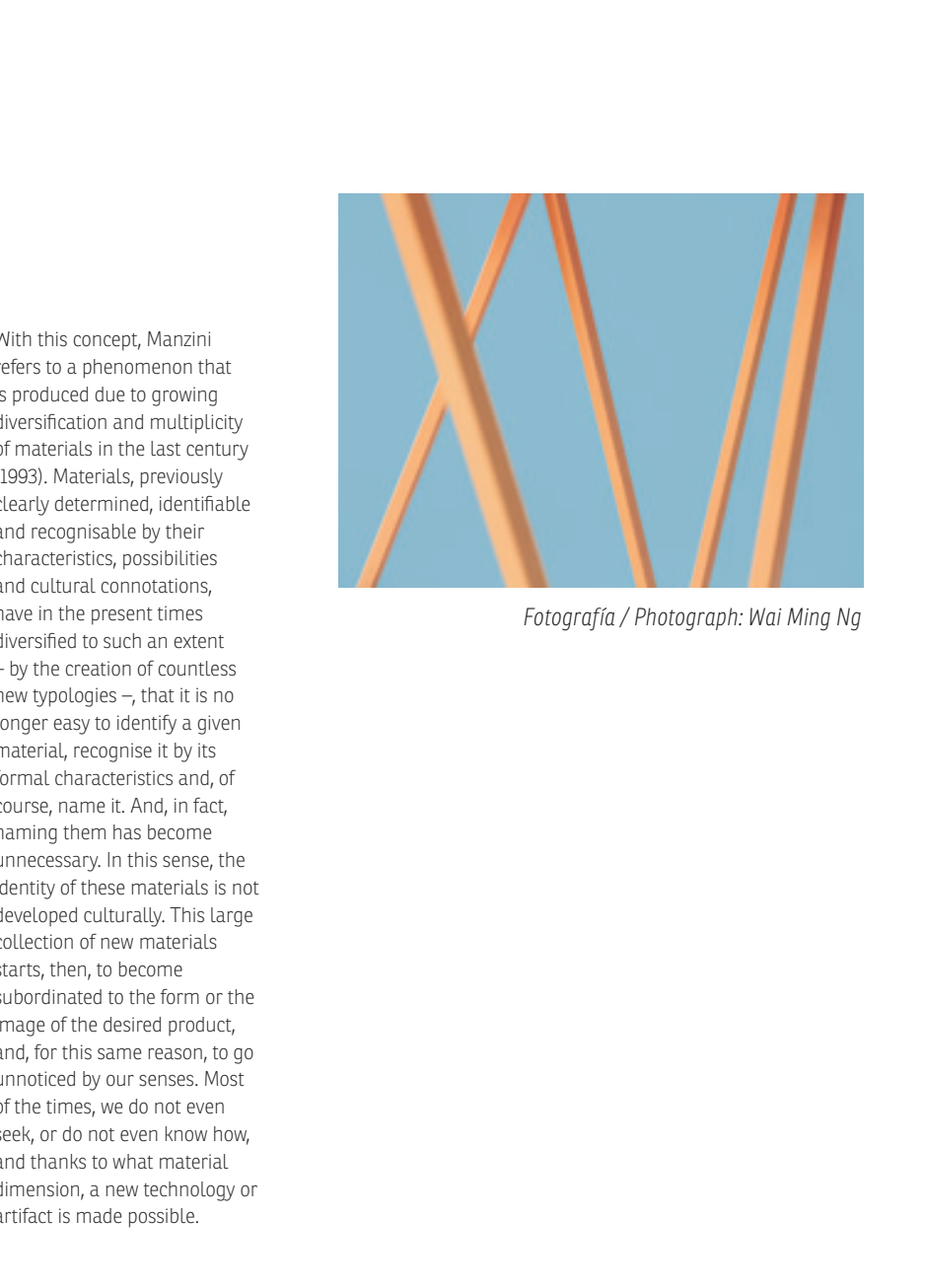

From this perspective, Ingold insists (2010), the focus of the studies on the processes that originate form and allow is growth, circulation and materia 政 the function of proderding to this log artists, or designers - in the universe matters, combining and redirecting their flow towards what could emerge and ss already prefigured in their natura thateriask of the producer is not to dea, but to unie and follow the fores and flows of mater tollow the forces the form of the work.

From design theory, the material Manzini, who in the context of a growing 'crisis of identity' of materials $s^{1}$ underlines the value of presence and behavior. of materials as agents that, althoug may frequently remain unnoticed, informassible our present society of xistencen, and even make possible the

present-day scenario: 
de la inteligencia artificial. No

hay información sin soporte,

no hay informática sin silicio

monocristalino (o, en el futuro,
otros minerales); no podría haber

objetos de alta complejidad

e integración sin materiales

de también gran intensidad

de prestaciones. Si a nuestra

escala perceptiva los materiales

se vuelven menos invasores o

incluso llegan a desaparecer, esto

no significa que su papel haya

disminuido. sus prestaciones son,

por el contrario, tan elevadas,

advertir casi la causa» (Manzini,

1993, pág. 37.

Van Aubel opera en este contexto, consciente de que existe un ejercicio
político de los objetos: en la medida en que estos asumen poder en sus espacios de uso y circulación, pueden generar cambios a nivel de habitabilida y en la forma en que las personas se relacionan, perciben y piensan el

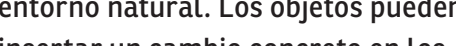
estilos de vida, modificando aquellos hábitos que contribuyen a la actual crisis mbiental. Van Aubel concibe el diseño como un medio para cambiar el modo en que las personas se relacionan con el ecosistema, especialmente a partir de la interacción con los objetos de diseño sustentable. Este último punto es especialmente relevante en relacio con sus proplos proyectos, en los que solo en la seleccín de materia y procesos de producción, sino también a través de la intención de estos objetos, orientados a generar cambios en las prácticas y comportamientos de los usuarios a traves de su funcionalidad, así como a través de su capacidad para insertar la problematica medioambienta estético (comun estro (2017).
The new materials are the spectacle of communications, of the computerised imaginary, of artificial intelligence. There is no information without medium there is no informatics without monocrystalline silicon (or, in the couldn't be any highly complex, integrated objects without materials also of great intens in capabilities. If at the scale of our perception, materials become Less invasive or are even able to disappear, this doesn $t$ mean tha their rote has decreased: their capabitties are, on the contrary, so without perciving the cause" (Manzini, 1993, p. 37).

Van Aubel operates in this context objects: as they assume the power in the spaces of use and circulation, they may generate changes in habitability and in the way in which people relate, perceive and think the natural environment. Objects may insert a concrete change in the lifestyles, modifying those habits tha contribute to the present environmental a medium to change the way in which people relate with the ecosystem, especially through the interaction with sustainable design objects. This last point is especially relevant in relation with her own projects, where the sustainable nature is observed not only in the selection of materials and production processes, but also through the intention changes in the practicas generating of their users through their functionality as well as through their ability to insert the environmental problematics into the daily space through the aesthetic factor (personal communication, January 13, 2017.
TRES FORMAS DE AGENCIA EN EL TRABAJO DE VAN AUBEL

Como se ha dicho, la agencia observada en tres direcciones: la funcionalidad, la composición material y la estética con la efectiva capacidad de acciones sustentables que puede desencadenar un objeto a traves de su funcionalidad (2015) en ventan de paneles solares que capta ba uzy convierte en corriente eléctrica disponible para cargar dispositivos electrónicos. El objeto, dispuesto en su contexto de uso, es funcional $y$ eficiente, en tanto actúa como generador $y$ mediador de energi renovable (energía solar). A través de la forma en que opera, Current Windo cos usuarios, indinacis cotidanas de sustentable, trocando una tecnología tradicional de iluminación de una habitación (ventana) y la fuente de recarga de los dispositivos electrónicos en un dispositivo que efectivamente vincula las personas con la luz y la energía solar. La segunda forma de agencia de los objetos - composición materialestá vinculada a la capacidad de

La materialidad de los objetos para

determinary modncar las formas de

produccion. Tal es el caso de Well Prove

base de un nuevo material creado por

Van Aubel y James Shaw a partir de

desechos de madera y biorresina. La

materialidad efectivamente determina

las condiciones, los costos y el impacto

ambiental de los procesos de produci

La invención de un "nuevo material",

usando el concepto de Manzini (1993), trae aparejado, en este caso, un producción con menor impacto
de prodo medioambiental, asi como la reutilizacon de virutas de madera desechadas durante la producción de sillas fabricadas a partir de procesos productivos convencionales. Finalmente, destaca la agencia de estos objetos de diseño en el sentido estético, es decir, la forma en que la dimensión sensorial o sensual puede interpelar la percepción de los usuarios en favor de o, si se quiere del desarrollo de una 0 , si se quire, del desta
THREE FORMS OF AGENCY IN THE WORK OF VAN AUBEL

As stated before, the agency observed in van Aubel's projects would operate in three directions: functionality, material composition and the aesthetics of the atchat capacty of sustainable actions functionality As is trigger through its Window (2015), a window built from sols iliges light and converts electronic devices. The object, set into its acting as generator and mediator of conditionserates, Current Window disposing the daly practices of users, combining the traditonstlahnting technology for a room (window) and the power source for electronic devices into device that effectively connects people with light and solar energy.

The second form of agency of the objects - material composition - is materiality to determine and modify the forms of production. Such is the case with Well Proven Chair (2013), a created by van Aubel and James Shaw from wood scrap and bio-resin. The materiality effectively determines the

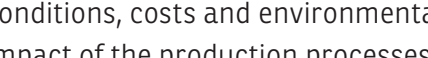
The invention of a 'new' material, using Manzini's concept (1993), brings along, in this case, a production process with a much lower environmental impact, as we as the reusing of wood chips discarded conventional production processes. Finally, the agency of these design sense, that is, the way in which the sensory or sensual dimension may address the perception of their users in favour of a greater attention to the issue of the environmental crisis or, for the development of greater environmental awareness.

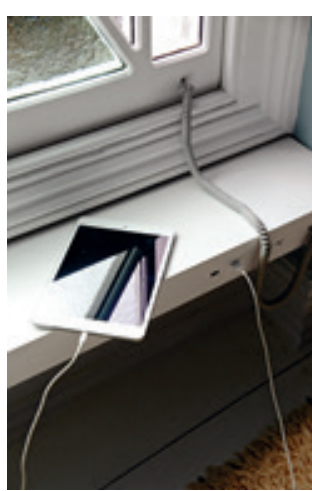



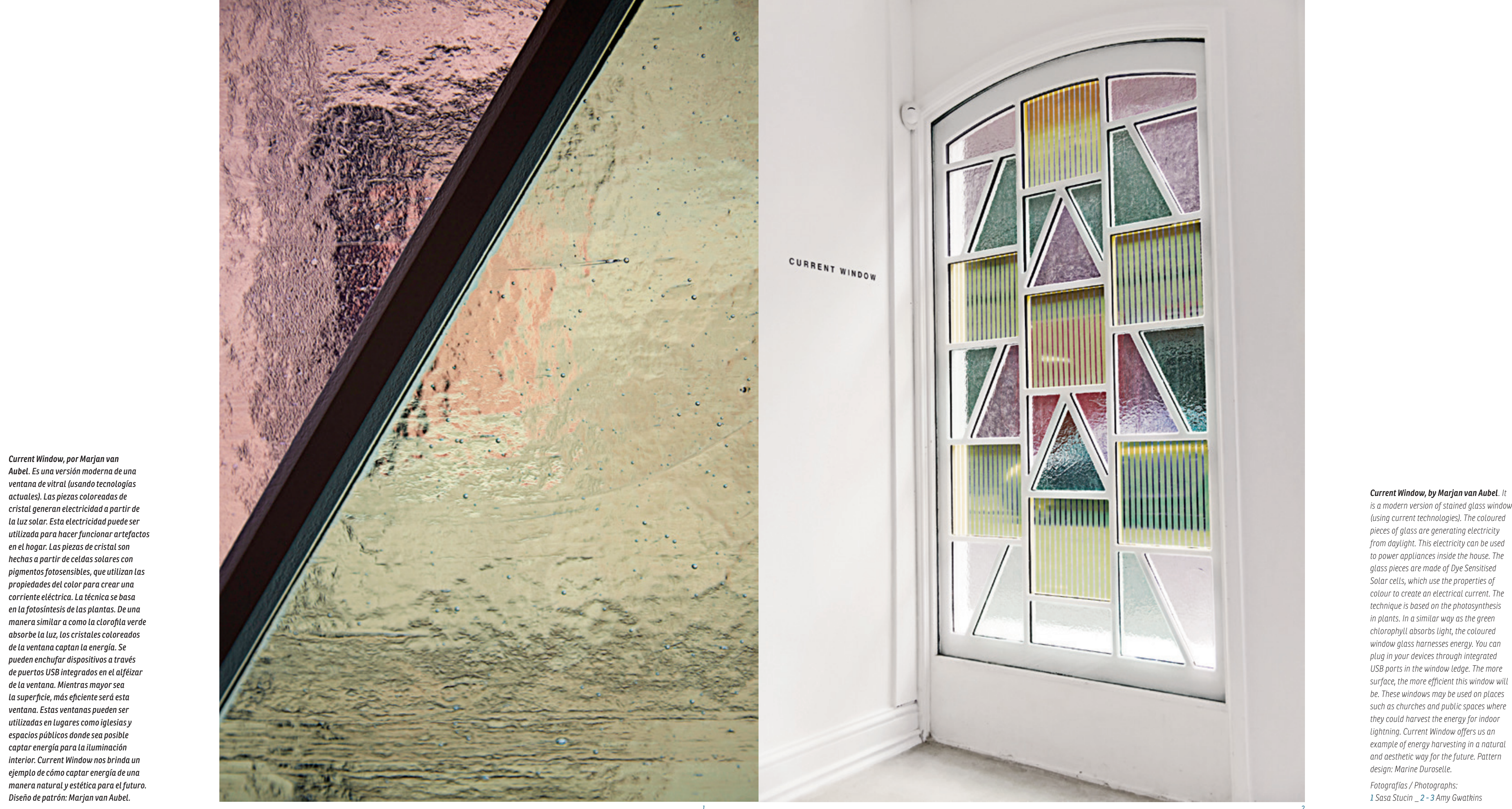

Tanto Current Window como Current Table (2014)

son objetos que, al interactuar funcionalmente con el

usuario, implican o determinan una respuesta que resulta amigable con el entorno.

Both Current Window and Current Table (2014) are objects that, when functionally

interacting with the user, imply or determine a response that is environmentally friendly.

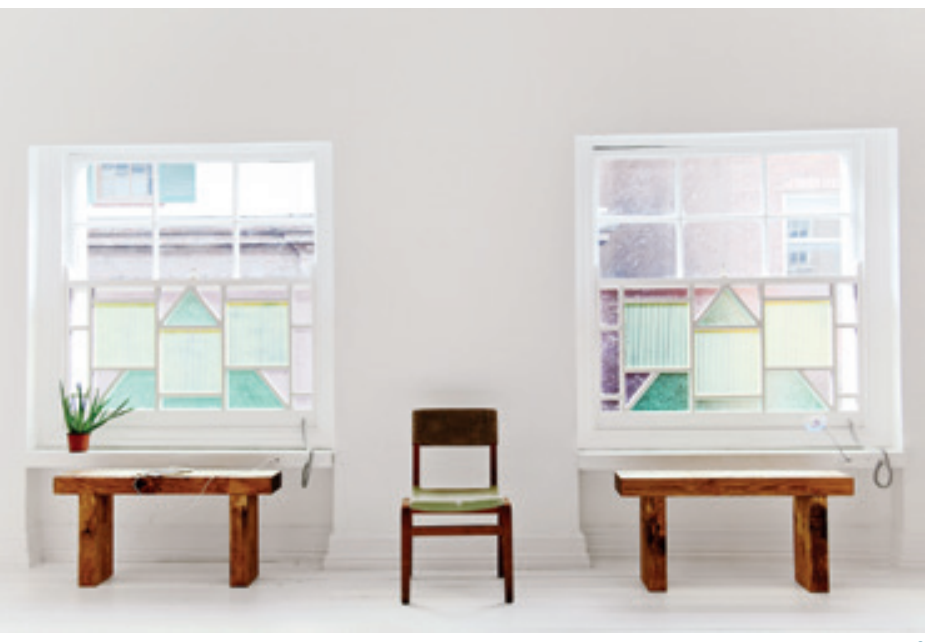


En este caso, las expresiones de la materialidad en Well Proven Chairy
Current Window develan y manifiestan el problema de la actual crisis

medioambiental. En el caso de Well

Proven Chair, la gesta y desarrollo de

la producción material sustentable

perningere en la visualidad de ta silla, cargando con ha hullo se supoce de producción material. Este nuevo

material se explaya exhibiendo belleza versatilidad y planteando, con la evidencia de su propia constitución, la posibilidad de transformar las prácticas productivas para
la generación de objetos de uso moderno.

FUNCIONALIDAD

GENCIA MEDIOAMBIENTAL

Quizá esta primera esfera de análisis

sea la más directay de fácil comprensión.

Tanto Current Window como Current

Table (2014) son objetos que, at interactuar fancionalmente con el usuario, implican o determinan una respuesta que resulta a conecar equipos electrónicos a su fuente energética, estos objetos permit prescindir de la energía eléctrica convencional y hacer uso de la energía renovable obtenida a partir de la luz solar. Lo interesante es que la intencionalidad sustentable existe ya en el objeto, está prefigurada en este, por to que la condición que la práctica llevada a cabo en la interacción con el usuario sea también sustentable. En este sentido, el compro de Van Aubel de crear objetos que influyan en la modificación de prácticas cotidianas de las personas para aminorar la crisis medioambiental se da, primeramente, en la funcionalidad de estos objetos, cuyo uso conduce inevitablemente a movimientos $\mathrm{d}$ Pror macho ambiental.

Por otra parte, la forma en que ancionan estos objesos es también un dependia y el medio ambiente, así como una experiencia que permite asimilar que ta Luz solar no es permanente, sino efímera $\mathrm{y}$ variable. Esto se debe a que tanto la ventana como la mesa de corriente so

objetos que dependen de la interacción con la luz solar para funcionar, lo que this case, the expressions of materiality in Well Proven Chair and Current Window reveal and manifest the problem of the of Well Proven Chair, the conception and development of a sustainanle material remains in the visibility of the chair, which enters the spaces of circulation bearing the footprints of its processes of material itself exhibititng beauty and versatility an manifesting, with the evidence of its own constitution, the possibility of transforming the productive practices for the generation of objects for contemporary use.

FUNCTIONALITY AND

ENVIRONMENTAL AGENCY

Perhaps this first sphere of analysis

is more direct and easier to understand
Both Current Window and Current

Table (2014) are objects that, when

functionally interacting with the user, mply or determine a response that is environmentally friendly. Indeed, when power sources, these objects can go without conventional electric power and use the renewable energy obtained from the sunlight. The interesting thing is that the sustainable intentionality already exists in the object, it's prefigured in it, so the condition and the way to operate these objects determines that the practice performed in the interactions with the users van Aube's commitment to create objects that have influence on the modification of everyday practices of people to reduce the environmental crisis, is based primarily on the functionality of these objects, whose use inevitably leads to movements of lower environmental impact.

On the other hand, the way in which these objects function is also a contribution to the awareness in the relation of dependency between human an experience that hass asimita sunlight is not permanent but shortlasting and variable. This is because both the window and the electric table are objects that depend on the interaction with sunlight to function, implying that the successful interaction of the object
Current Table, por Marjan van Aubel. Un
mueble puede ser una fuente de energia. Unaestaciön de trabajojp puedef funcionar como su medio ambiente para cargar a r tefefactos. En estac colección de muebless objejtos, La e nergia

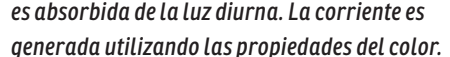
La mesafunciona como un sistema especial que capta y almacena energia transferible. Es

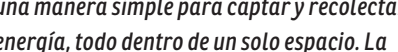
superficiede la mesa es hecha de cristal coloreado. Dentro del cristal hay una capa

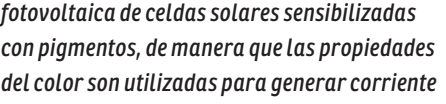
electrica. De manera similara c comol a clorofila verdeabsorbe la luz, los coloresen la mesa capaces de funcionar en interiores bajo luz difusa, a differencia de las celdas solares convencionales, que requieren luzsolar directa comosuperfficiede trabajo y como batería. La utilidady la esteteitic se combinan a traves dele uso de la energia solar en o objetos cotidianos. stimuleringsfondsy manufacturadas por Solaronix (Luusanne, Suiza). Dimensiones:

Current Table, by Majjan van Aubel. Afurriture could be a source of energy. solar cell gathering energy from its environment
to charge appliances. In this collection of furniture and objects, energy is absorbed from daylight. The electric currentis created by
using the properties of colour. The table works as a unique system that collects and stores
transferable energy tis s simole way to o ate and harvest energy all within one r room. The

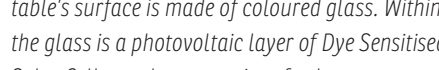
Solar Cells, sothe properties of colour patterns

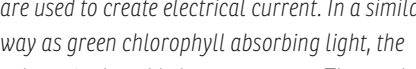

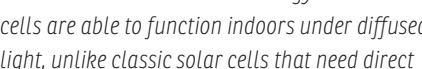

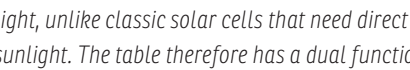
both as a works sufface and as a battery. Utility of Solar energy in veveryday objects. The DSSC Solar cells have been kindly sponsoreded by the Solaronix LLausanne Switzerland). Dimensios Solatann $x$ CLausanme
$145 \times 105 \times 70 \mathrm{~cm}$.

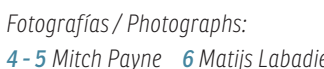

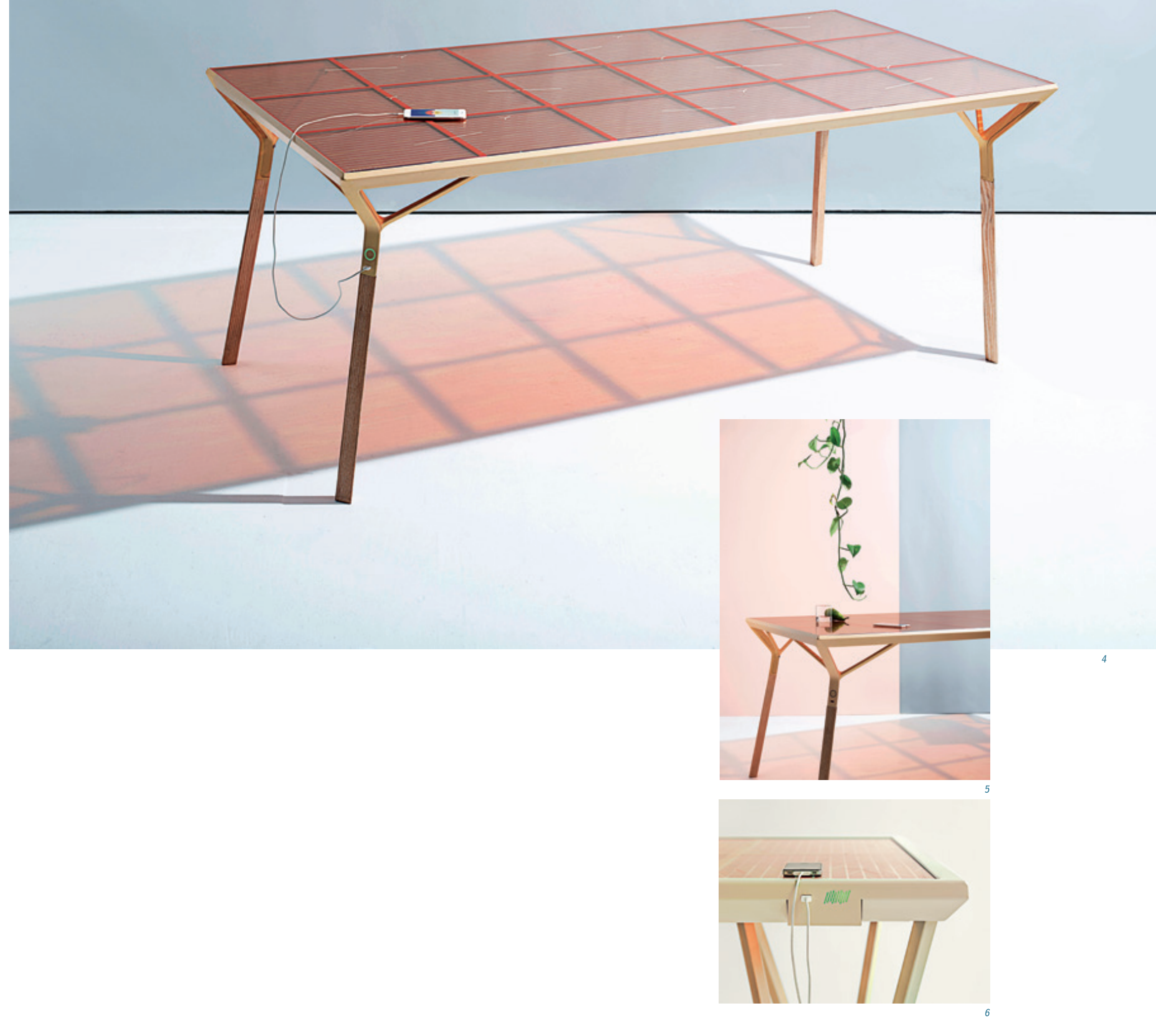



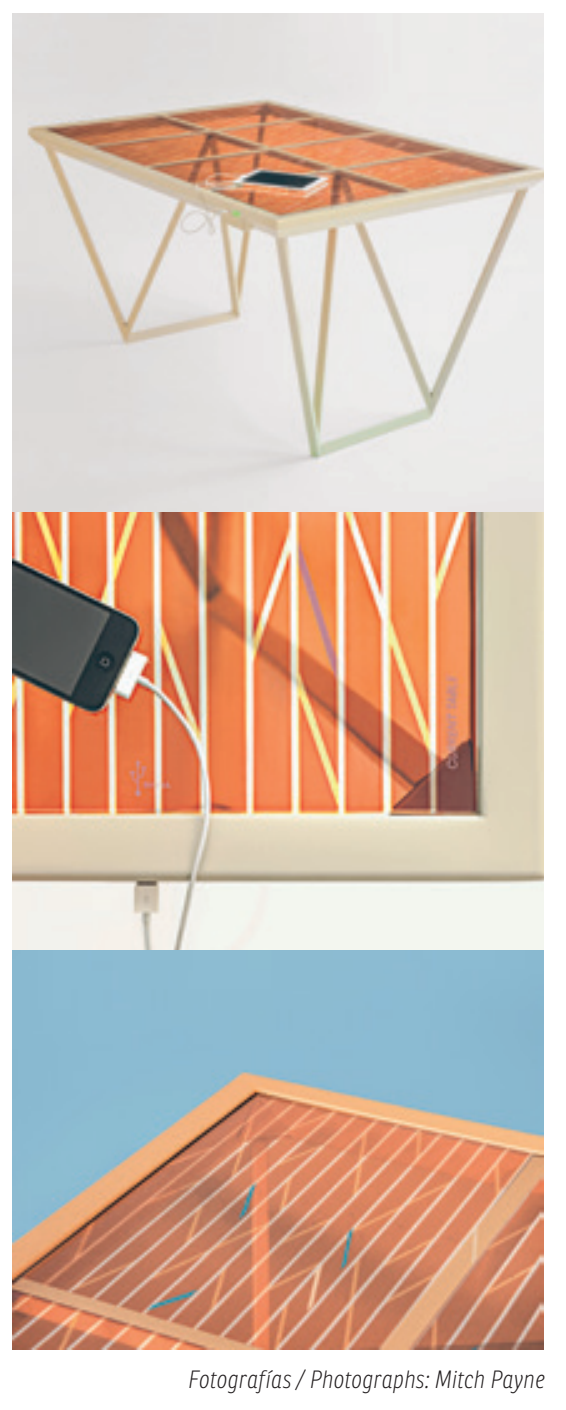

objeto con el usuario dependerá no solo de with the user will depend not only on the intention of the latter of connecting a este dispositivo, sino también del estado to this device, but also on the level of de carga de luz solar del objeto. Dado que sunlight charge of the object - or at a menudo la experiencia cotidiana de la least, it will strive not be affected by it vida moderna prescinde de las variaciones or by other climatic conditions - , the de la luz del sol -0 al menos se esfuerza functioning of the window and the table por no verse afectada por ella ni por otras generate an experiential connection de la ves del $\begin{array}{ll}\text { vinculación experiencial que manifiesta verification that it's a constantly } & \end{array}$ nuestra dependencia de la luz natural, y la changing source of energy-constatación recurrente de que es fuente Additionally. it's interesting to point de energía en permanente variación. Autditionalty, it's interesting to point Adicionalmente, es interesante señalar agency from a functional perspective que los proyectos en cuestión presentan as they have the capacity to potentiate agencia desde el plano funcional en their functionalities, minimizing material, tanto tienen la capacidad de potenciar energetic and spatial waste. In all these sus funcionalidades, minimizando el cases, it's about objects conceived to derroche material, energetico y espacial. perform simultaneously more than on En todos los casos se trata de objetos function, and that, for this reason, are más de una función, y que, por lo tanto, ways, contributing in this manner to the interactúan de múltiples formas con los efficiency of private spaces, Van Aubet usuarios, aportando de esta manera a declares she's seeking to stress the la eficiencia de los espacios privados. functionality of everything she builds, Van Aubel declara que está buscando namely, that an object can perform more extremar la funcionalidad de todo lo than one function at a time (personal que construye, esto es, que un objeto communication, January 13, 2017). In this pueda cumplir mas de una funcion a ta sense, it becomes relevant that Current 2017) En este sentido, Conl, 13 de a que Current Window o Current Table sean a re not simply reduced to solar panels, ventanas y mesas, que funcionen como which would force users to consume, tales y no se reduzcan simplemente a install and use, additionally, windows and paneles solares, lo que obligaría a los usuarios a consumir, instalar y ocupar, adicionalmente, ventanas y mesas para suplir tales necesidades.

NUEVOS MATERIALES QUE GESTAN CAMBIOS EN LOS PROCESOS DE PRODUCCIÓN Manzini identifica un sentido acotado y un sentido amplio del concepto "nuevos materiales". El primero queda circunscrito a los materiales «entrados disponibilidad, a nivel experiment productivon (1993, pág. 41), es decir los materiales que, concretamente, son "nuevos" y no existían previamente en la historia de los materiales. En su sentido amplio, en cambio, «los

nuevos materiales no son solo nuevos polimeros, nuevas aleaciones, nuevas
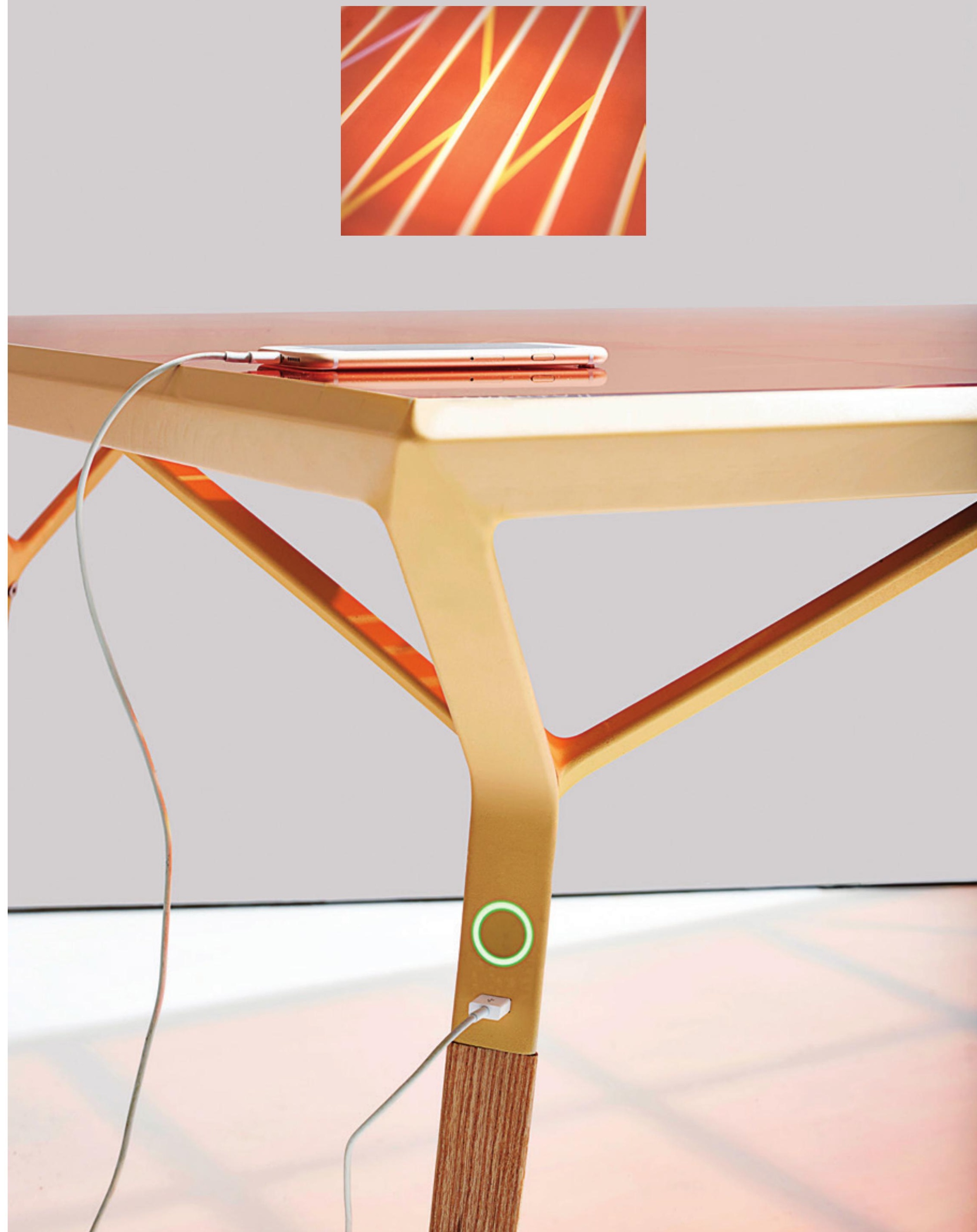

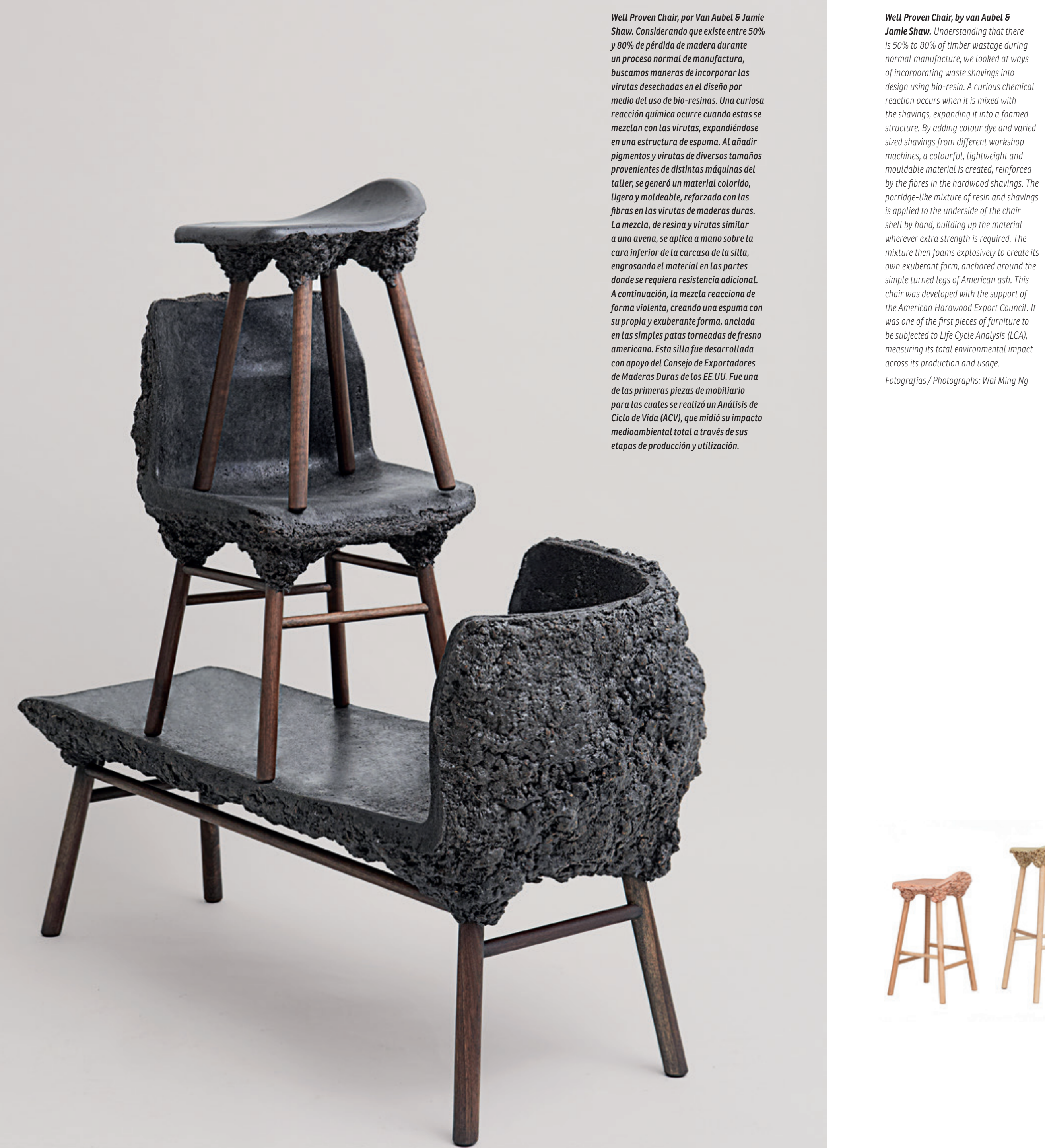

Podemos definir "nuevos" también los materiales que nacen de la combinació creativa de materiales conocidos»

(Manzini, 1993, pág. 42), lo que implica

que «no son necesariamente el fruto de la investigación de grandes laborato su producción puede proceder de productivos (Manzini, 1993, prayectu Ensu mplosentide, el materia de Well Proven Chair constituye un "nuevo material" en tanto que un la combinación de virutas de madera -antiguo y noble material - y una biorresina o resina ecológica. Asi también, es un material que no nace en grandes laboratorios, sino a una escala pequena, en un taller de onclo artesano, de error y acierto de los autores dan lugar a un material que funciona en determinadas condiciones.

Uno de los aspectos más relevantes de este nuevo material está asociado a su origen: el deseo de reutilizar un material de desecho para producir nuevos objetos, a través de procesos que impliquen menor impacto amblental. En este caso de mader a ce se creación de las patas aue se utilizán en esta silla, por lo que se utiliza todo el material que se desprende del proceso de producción de este objeto. El color se ajusta según la tonalidad natural de los distintos tipos de madera. Los asientos fresnoy café para de mer, a nanto resta yace para la madera de nogal. De al diseño y producción de materiales no va tanto en el uso de materiales naturales sino principalmente en considerar la vida completa de un material (Dent, 2007).

Esta oportunidad que ofrecen los

nuevos materiales es sin duda uno de sus principales aportes a la sustentabilid eñala que:

«En el cuadro de la manipulación más refinada de la materia y del uso más cuidadoso de la energía, los nuevos materiales ocupan una posición centrat no solo en terminos de coste también de coste energético global (esto es, del material, del proceso de transformación y del consumo en la vida del producto). (...) La problemática de la energía se entrelaza finalmente con la de los nuevos materiales tambie porque estos estan en condiciones de ampliar el campo de los recursonibses (1993, pág. 44). materials that are born from a creative anzini, 1993, p. 42), which implies that "they are not necessarily the product in the projective or prom any place (Manzini, 1093, p. 42).

In a broader sense, the material in the Well Proven Chair constitutes a 'new material, since it is born from the and noble material - and an ecologic bio-resin or resin. Likewise, it's a materia that isn't born in Large Laboratories, but in a smaller scale, in an artisan's shop, where experimentation and the exercising of trial and error of the authors, originate a materiat that functions under particular conditions. One of the most relevant aspects of this new material has to do with material to produce new objects through processes that imply a lower environmental impact. In this case, the waste material is wood chips generated from the manufacturing of the legs that will be used in this chair, so all of the material that comes out of this process is used. The colour is adapted to the natural tonally of the different aspes of wood. Pink seat uses cherry legs, This way, the sustainability associated with the design and production of materials is not so much related to the use of natural materials, but mainly in considering the complete life-cycle of a material (Dent, 2007).

This opportunity that new materials offer is clearly one of the key contributions to sustainability. In this respect, Manzin points out that:

"In the framework of the most refined manipulation of matter and most careful use of energy, new materials occupy a central place not only in terms of energy cost per unit of weight, but also of global the process of transformation and the consumption during the object's Life). (...) The concern about energy is finelly intertwined with that of new materials also because these have of available resources" (1993, p. 44). 

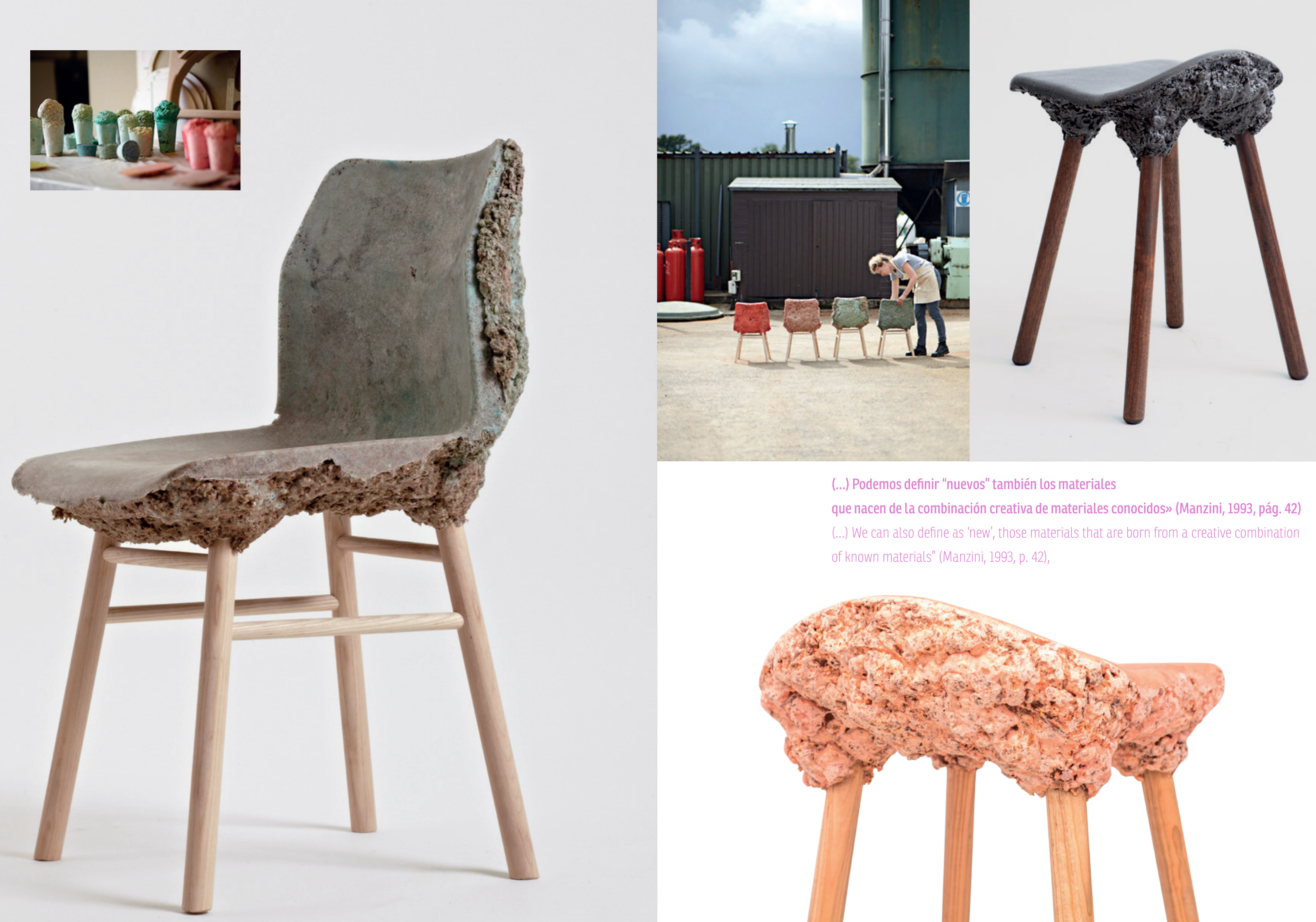

(...) Podemos definir "nuevos" también los materiales

que nacen de la combinación creativa de materiales conocidos» (Manzini, 1993, pág. 42)

(...) We can also define as 'new', those materials that are born from a creative combination

of known materials" (Manzini, 1993, p. 42),

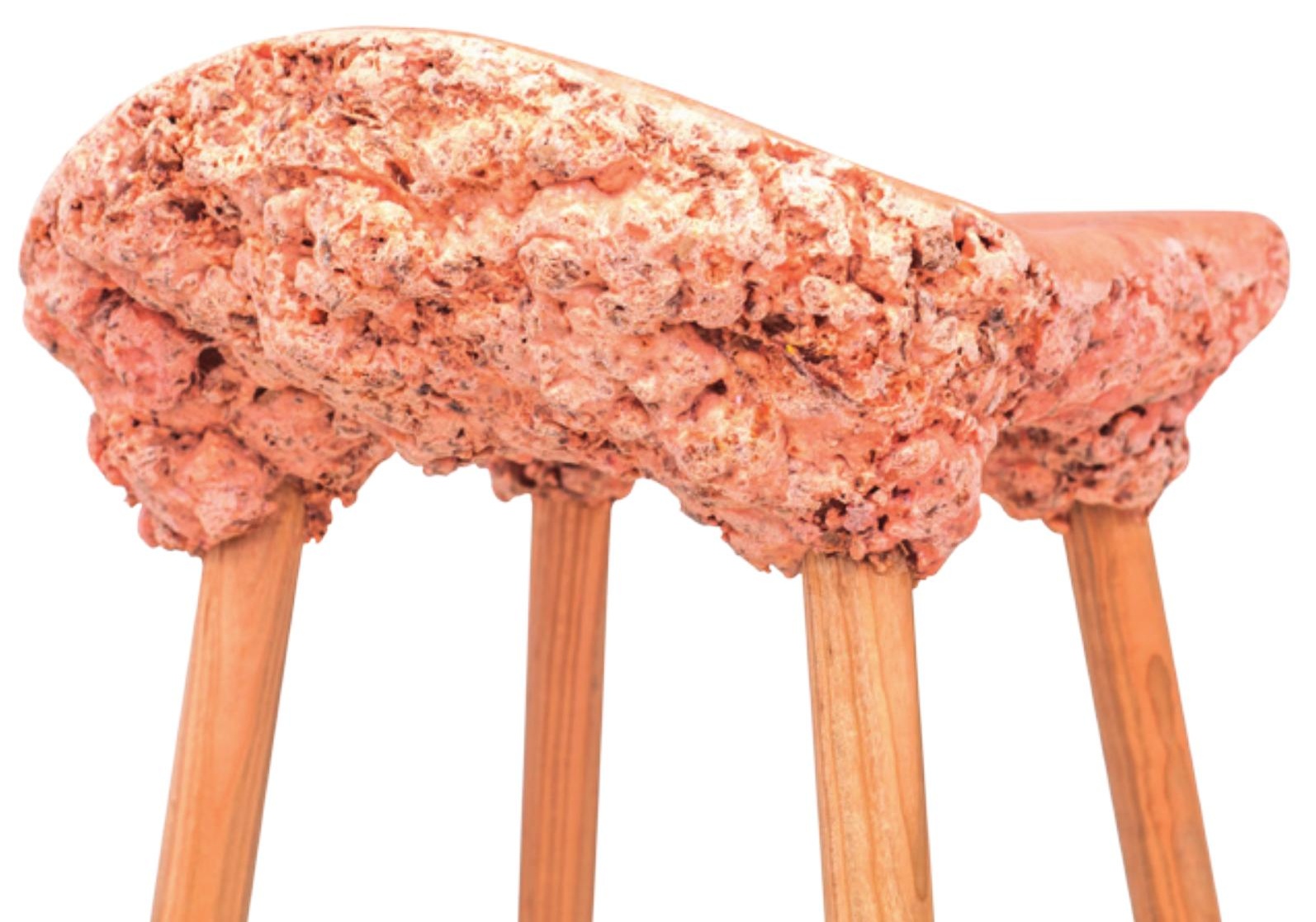


En este sentido, interesa pensar que los materiales, sus propiedades y sus procesos determinan el tipo de prácticas yvida útil que se realizan en la esfera actual, y que altiradica una importa gencia de los materiales en relación época. La elección de trabajar con un nuevo material que implica menor cos ambiental repercute en las formas en que la industria y los productores va a funcionar. En el caso de Well Proven Chair, La invención y la decisión de utilizar un nuevo recurso se transforma en la agencia del material de determina medios, circuitos, procesos y mano de obra específicos, acordes a

\section{LA ESTÉTICA EN LA OPERACIÓN}

PDĹTICA DEL DISEÑ

La agencia de los objetos de diseño th un sentido estético se puede vincular "stética cotidiana", destacan los autores Katya Mando (1994), Yuriko Saito (2007) y Luis Herná Errázuriz (2015). Estos estudios apunta a destacar la importancia del factor estético en múltiples dimensiones personales y sociales, en términos éticos, politicos y educativos. La profesora Yuriko Saito ahonda en este "poder de la

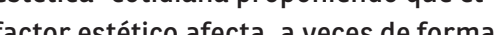
determinante, a calidad de vida y el estado del mundo (2007) La principat tesis de Saito colinda con la que se ha propuesto en este artículo, en tanto los aspectos sensuales de los objetos tienen consecuencias relevantes en erminos ambientales, morales, sociales politicos (2007), especificamente a personas y objetos. Si bien es cierto que tos os objetos cotidianos está impulsado por su funcionalidad, es necesario reconocer que se produce inevitablemente un contacto estético con las características sensuales de estos objetos, lo que genera repercusiones importantes en otros

Thes de la existencia himana.

Inevitablemente, los aspectos visuales, formales, tactiles y proporcionales de los
objetos condicionan la forma en que nos
In this sense, it is interesting to consider that materials, their propert type of practices of production,

transportation, circulation and service life that are currently carried out, and hat here tays an important agency of processes of an era The choide of

a lower environmental cost impacts

the ways in which the industry and the manufacturers are going to work. In the case of Well Proven Chair, the invention, and the decision of using a new resour become the agency of the material of determining specific ways and means, circuits, processes and labour, adeq

THE AESTHETIC IN DESIGN'S POLITICAL OPERATIONS

The agency of design objects in an of what has been called 'everyday aesthetics', where authors like Katya Mandoki (1994), Yuriko Saito (2007) and Luis Hernán Errázuriz (2015) stand out. These studies aim at highlighting the multiple personal and social dimensions in ethical, political and educationat terms. Professor Yuriko Saito delves into this "power of everyday aesthetics' proposing that the aesthetic factor affects, quality of life and the state of the world (2007). Saito's main thesis concurs with what has been posed in this article, that the sensual aspects of objects have relevant consequences in environmenta moral, social and political terms (2007), specifically through the daily interaction between persons and objects. Althoug interest for everyday objects is trigger by their functiona ojects is triggered acknowledge that, inevitably, an aesthe contact is produced with the sensuo characteristics of these objects, which in urn generate important repercussion in and proportional aspects of objects

condition the way in which we rela relacionamos con ellos, la disposición que tenemos a interactuar $y$, finalmen interacción en nosotros. En este sentida, el factor estético del entorno cotidian no puede verse como un elemento secundario de la existencia humana o de a cosas El trana derom opera considerando que la estética de los objetos de diseño condiciona las interacciones que estos llegan a tener con los usuarios y el éxito que pueden alcanzar en la ulterior modificación de prácticas cotidianas de las personas, es decir, en su potencia como agentes de cambio socioambiental, como se tha diseñadora seña pue a través de combinación de la energía solar con ta belleza o el atractivo visual aue aporta el diseño, es posible crear productos capaces de integrarse fácilmente en vida cotidiana actual, permitiéndonos vivir con energía solar y facilitando la disposición que tenemos a adquirir productos de este tipo (comunicació intención de Van Aubel es fundir atractivo visual con el factor funcion esto es, generar un objeto cuya belleza descanse en una coherencia, radical y sencilla, entre las propiedades visuales $y$ funcionales de los materiales $y$ el objeto. En el caso de la ventana y la mesa, la capacidad del objeto vidas se sostiene ampliamente en las condiciones formales de los materiales. Es así que se vuelve necesario recordar. que los paneles solares utilizados son coloreados, y que se ha optado por

colores adecuados para la captación de luz, en coherencia con la función de la clorofila que hace posible la fotosintesis del del color hace gran parte de la tarea de valor en términos visuales Así agrega destaca la forma de los paneles solares, dispuesta en figuras geométricas que al operar sobre la base de líneas rectas. them, the disposition that we have to interact and, finally, the inner sensation that this interaction creates in us. In this environment cannot be understood as a secondary element of human existence or of the human interaction with other persons or thigs. Manjan van Aubel's ansthetics of design objects conditions the interactions that these will have with the users and the sucess may have in subsequent modifications of people's everyday practices, that is, in their capacity as agents of socialenvironmental change, as has been argued until now.

During a personal interview, the designer pointed out that through the combination of solar energy and the visual appeat that design provides, its capable of merging easily into every life, allowing us to live with solar energ and facilitating the disposition that we normally have to buy this type of products (personal communication, January 13, 2017). The intention of van Aubel is to fuse together this visual appeal with the functional factor, that is, to generate and simple conerence between the vis and functional properties of materials and the object. In the case of the windo and table, the capacity of the object of bringing solar energy to our lives is supported to a great extent by the forma conditions of the materials. It becomes, thus, necessary to remember that the solar panels used were coloured, and that for the capturing of light This as coherent with the function of chlorop that makes photosynthesis possible in green vegetables. The property of colour makes a great deal of the task of capturing light, adding at the same time value in visual terms. Equally relevant is the shape of the solar panels, arranged in geometric shapes favouring the straight-line schemes.
Los objetos se conectan visualmente través de otros elementos, natural serción de ciertas líneas que hace Un guino a formas frecuentes en la aturateza vegetal. lineas pulcras, que en una primera lectura se vuelv nen interacción permanente del medio ambiente con el espacio privado. E el caso de Current Table, la superficic de la mesa opta por líneas de diseño que establecen una analogía con las ervaduras de hojas vegetales, que in de cuentas son también canales que permiten la crullacion de cortente pas pas su par. La forma estructura de ramificación de los árboles. En el caso de Current Window destaca la importancia del ingreso de la luz solar como elemento que activa visualmente la ventana, sus colores, sus formas y su condición translúcid evidencia la frecuente interacción

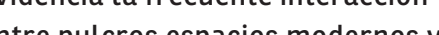
entorno natura. Esto implica esde sencillas soluciones formales, el bjeto no solo se vuelve más atractivo deseable en terminos visuales, sino que presenta una coherencia discursiva esta propuesta sustentable que se Adicionalmente, es importante señalar que ta estética de los objetos To se reduce a su atraclivo visual, 0 veces se confunde, sino que se refiere a todos aquellos elementos del objeto que interpelan la percepción sensoria y experiencial-corporal de los usuarios, y que nos reconectan, a través de la percepción, con un sentido y conciencia ta problemática medioambiental. caso de Well Proven Chair, la expresión elos factores más relevantes en este sentido. La forma en que se comportan aparecen a nuestra percepció sin duda a la construcción semántica y a la definición del propio objeto, pero tambiên a una forma distinta de "entra" en este sentido medioambientalista y

de acceder a la conciencia dela crisis los nuevos materiales.

The objects connect visually with the aesthetics of the natural environ inclusion of certain lines that mimic forms that are frequent in vegetables: clean lines, which at first reading become an abstract language, but that for a lormant interire environment and private space In the case of Current Table the surface of the table chooses design lines that establish an analogy with the structur of vegetable leaves that, in the end, are also channels that allow the circulation of electricity through these structures. The shape of the legs, on the other han resembles the branching structure the importance of sunlight intake as an element that visually activates the window, the colours, its forms, and its Iranslucent condition. These are all forms that demonstrate the frequent interaction between clean modern This implies that rot environment. solutions, the object not only becomes erms, but presents a discursive sustainability that is also observed in the functionality.

In addition, it's important to point out that the aesthetics of an object is not limited to its visual appeal, or to the decorative aspects with which it's so requently confused, but refers to all the the sensory abject that interpellate problem. In the case of Well Proven Chair, the aesthetic expression of the most relevant factors. The way in which they behave or appear before ou perest, to the f the object itself but a ts to a differion way of 'entering' into this environmental sense and accessing the amareness of al crisis associated with 
En el caso de la silla, esta expresión sstética del material nos conduce
dos ideas que se tornan visibles, permitiendo a los usuarios-espectador acceder a este comportamiento del Gaterial por medio de la vistay el tacto. La primera idea tiene que ver con el coso ansformación que es capaz de ser un coproductor con el diseñador, como se referido previamente a partir de Ingold. La segunda idea corresponde a la condición de "nuevo material" que se utiliza en este trabajo, material confecciona a partir de un origen y a través de un proceso de menor impacto ambiental. se revan a trésés silla. Primeramente destaca el revés de los respaldos, espacio en el que aflora libremente el atractivo de la textura del nuevo material lgrueso, húmedo y burbujeante), rastro y huella de su proces de crecimiento y expansión. Asimismo, en el anverso del respaldo permanece

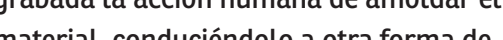
. lso y brilloso. El contraste y diálogo entre ambos planos, la belleza y el atractivo con que se desenvuelve la materialidad a atención que la diseñadora ha fijado en esta, constituyen una suerte de apología de los nuevos materiales y de su uso en eldiseño contemporaneo. una excelsa vía en la práctica y el futuro del diseño in ertando la sustentabilidad sin éxito funciona o estético de los objetos.

En craso de Current Window, et factor estético que nos inclina a a a conciencia de sustentabilidad tiene que ver con la retórica de la analogía que se establece entre la tecnología de energías renovables y el proceso natural de fotosintesis. La ventana explora materialmente esta analogía a traves de cunas visuales que referen a suti, no tan directa, representacionat il, amplían el acceso al sentido del mismo objeto, otorgándole posibles lecturas interpretativas, más allá de la mera propuesta de ciencia aplicada. Esto se observa, por ejemplo, en el uso del color y la forma de los paneles solares. deas that become visible, allowing the users-spectators to access this behaviour of the material through the senses of sight and touch. The first idea has to do with the repositioning of materiality as allving thing, in process, in constant co-producer with the designer, as has been inferred previously based on Ingold. The second idea corresponds to the

condition of 'new material' that is used in this work. A material elaborated from an origin and through a process of lesser environmental impact. Both premises become accessible or are revealed by being in contact wh the chair. Firstly, a space where the appeasting texts out, the new material (thick, moist, bubbly), the trace and footprint of its process of growth and expansion emerges freely. Similarly, the backside of the backrest preserves the human action of molding the material, driving it to a different form of behaviour that expresses a smooth and shiny character. The contrast and and the attractiveness with which the materiality unfolds, and the attention that the designer has invested in it constitute a sort of eulogy of new materials and their use in contemporary design: a superb demonstration of the potentials of this way in the practice and the future of design, inserting sustainability withou emaciating the object'st In the case of Current Window, the aesthetic factor that persuades us in has to do with the rhestric of the anablity that is established between renewable energy technologies and the natural process of photosynthesis. The windo explores this analogy materially, throug visual cues that refer to this process of photosynthesis in subtle ways, not too direct, representational or illustrative. These elements expand the accesses to the sense of the object in itself, endowing that lay beyond a more applied sciences proposal This is observed, for instance, in the use of colour and in the shape of solar panels. As we have seen, the
En el caso de la silla, esta

expresión estética del material nos conduce a dos ideas que se tornan visibles, permitiendo a los usuarios-espectadores acceder a este comportamiento del material por medio de la vista y el tacto.

As for this chair, this aesthetic expression of the materia leads us to two ideas that become visible, allowing the users-spectators to access this behaviour of the materia through the senses of sight and touch.
Como se ha visto, las propiedades de color (azul, verde, naranja) y son seleccionadas por su eficiencia funcional. Pero también son los elementos que, entre otros, conectan con la retórica de la fotosintesis, con un gesto poético que nos deja la sensacion y certidumbre a vida moderna hacia nuestra estrella. Finalmente también a través del uso de los objetos, cual performance que imp la corporalidad de los usuarios y la materialidad de las cosas en torno a u mismo plano de significado. Esto quiere decir que cuando un usuario efectivan conecta su dispositivo electrónico a Laventana solar, no solo se cumple (1) renovables en contextos cotidinos) sino que a la vez se cierra el ciclo poótico que refiere a la idea de la necesaria e inevitable dependencia de los seres humanos del sol. Este gesto se vuelve performativo completar el discurso y la acción de volver a conectarnos con este entorno natural asumiendoy reconoctendo la dependent real, fáctica - que nos vincula a esta fuente de vitalidad, tal como se asume reconoce en el mundo vegetal.

En este sentido, la acción política de los objetos se consigue no solamente a través de la interacción funcional de los usuarios con las cosas - a través de la cual Van Aubel consigue su cometido de modificar prácticas cotidianas-, sino tambiên a involucra desde la experiencia sensible con una problemática contingente, reforzando la convicción en el discurso y quehacer medioambientalista $y$, sobre todo, reconectando - una y otra vezcon el sentido de es properties of colour (blue, green, orange) selected for their functional efficiency. But they are also elements that, amon others, connect with the rhetoric of makes us awis, in a poetic gesture that the as the strong orientation of $\mathrm{hrl}$ as well fe towards our star.

Finally, this analogy is activated performance, that implies the bodies of the users and the materiality of things around a single plane of meaning. This is equivalent of saying that when a user effectively connects his electronic device to the solar window, he not only successfully meets the function for Which the project was designed (use

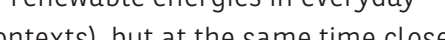
the poetic circle that refers to the notion of human beings' necessary and nevitable dependency on the sun. This gesture becomes performative when completing the discourse and the action of connecting again with this natural environment, assuming and acknowledging the dependency - symbolic, yet enormously source of vitality, just as it is assumed an cognised in the vegetable kingdom. In this sense, the political action of objects is achieved not solely through the unctional interaction of users and things goal of modifying everyday practices but also through this aesthetic plane that involves us from within sensory experience discourse and activities and, above all, econnecting us-time after time - all,

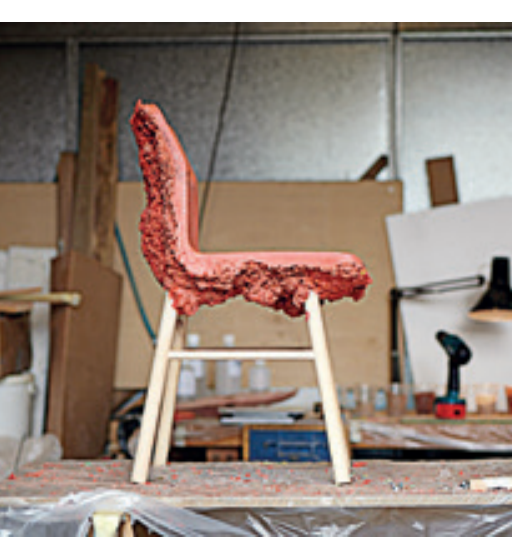


MARJAN VAN AUBEL

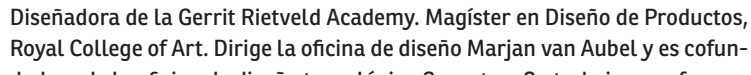

los materiales, la sustentabilidad, Latecnologiay la energía solar. Ha traba-

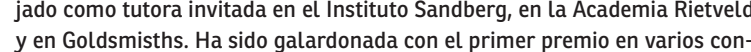

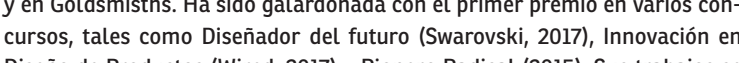

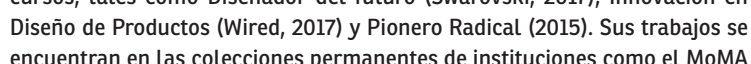

encuentran en las soleccioin
yel Museo de Diseño Vitra.

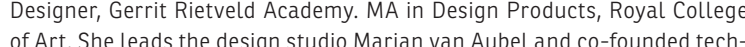
ter work is focused in materials, sustainability rechnology and solar energy. She has been visiting tutor at Sandberg varios competitions such as Designer of the Future (Swarovski, 2017), Innovation in Product Design (Wired, 2017) and Radical Pioneer (2015). Her work is in in the per
the MomA and the Vira Desion Muser

REERERNCES

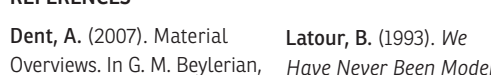

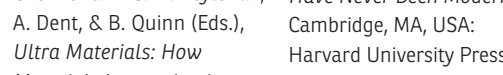

Ultra a aterials: How
Materials hnovation

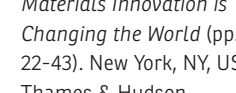

Domaniska, E. (2)

Archineologia Pollo
$44,17-185$.

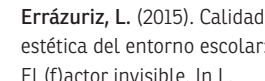

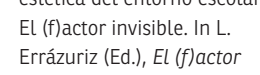

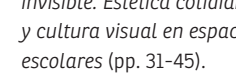

escolarese (pp. 31 - -45$)$.
Santiago, Chile Consejo
Nacional del la culturay

las Artes.
Gell A. (1998) A A

Geel, A. (1998). Art
and Agency An
Anthropological Theory.

New York, NY, US S.OP
University Press.
Ingold, T. (2010).

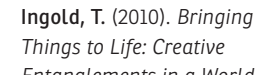

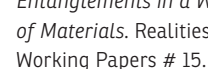

Miller, D. (1987). Mater

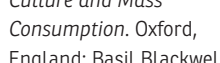

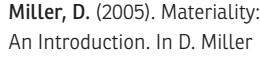

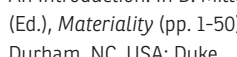

hersity ress: Du

Saito, Y. C2007) Everyday,
Aesthetics, New York, NY,

Woodward, I. C20011. Domestic

Epiphany: A Resource for
Consumption Methodology

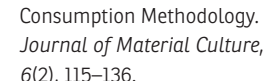

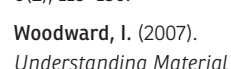

Understanding Material
Couture. London, England: SACE

列

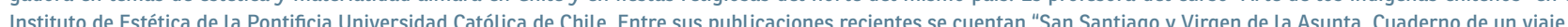

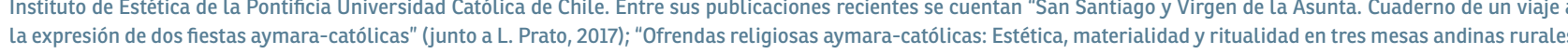
en Crile" Arctass dell X Congres
seres sagrados" (Diseña n n 10$)$.

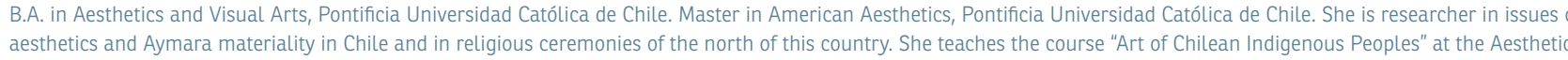

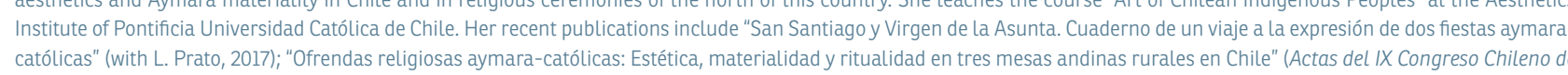

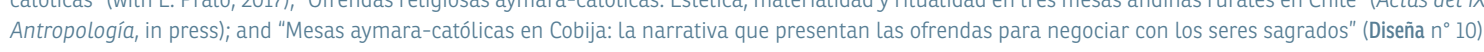

Ch.

$13-15$ Octubre

2017

Santia go, Chile

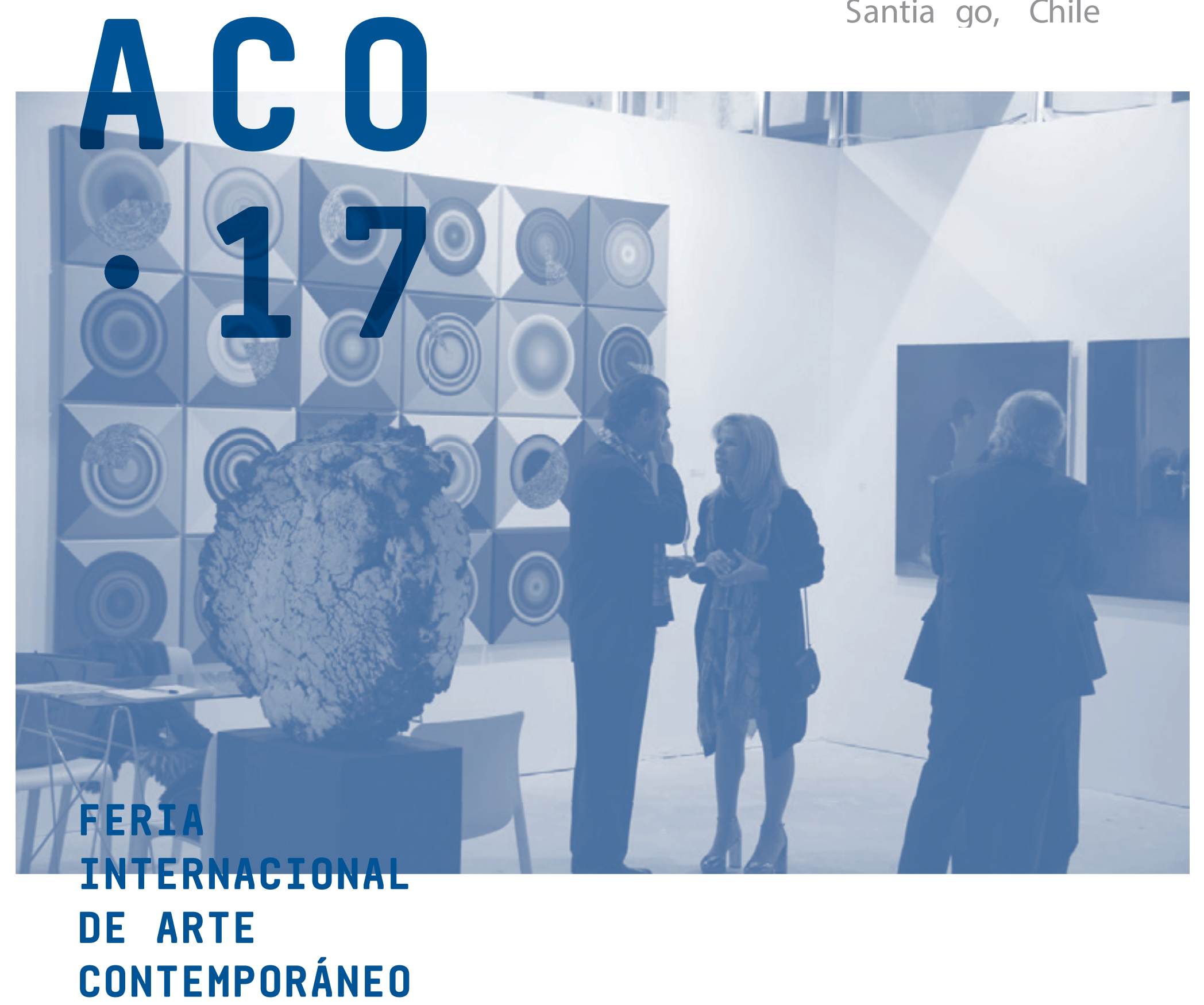

f /feriachaco
(0) aferiachaco
() aferiachaco

Www.chaco.cl 